УДК 616.98:578.828

DOI 10.11603/2411-1597.2021.2.12286

\title{
ОБІЗНАНІСТЬ МОЛОДІ У ПИТАННЯХ ВІЛ/СНІДУ
}

\author{
О. А. Полоз
}

Комунальний заклад «Олександрійський медичний фаховий коледж»

У статті висвітлено результати дослідження про рівень знань студентів медичного коледжу стосовно ВІЛ/СНІДу, способи передачі та профілактики, а також ставлення до ВІЛ-інфікованих.

\section{THE AWARENESS OF THE YOUNG PEOPLE IN THE QUESTIONS OF HIV/AIDS}

\author{
O. A. Poloz
}

\section{Municipal Institution "Olexandriya Medical Professional College"}

The article highlights the results of the study about knowledge level of the students of the medical college on HIV/AIDS, the way of transmission and prevention and the attitude towards HIV patients as well.

Вступ. Епідемія ВІЛ/СНІДу в Україні набула найбільших у Європі масштабів. Розвиток епідемії продовжує випереджати темпи боротьби з нею.

У жовтні 2020 р. в Україні офіційно зареєстровано 1244 нових випадки ВІЛ-інфекції, у 268 пацієнтів діагностовано СНІД, а 160 людей померли від СНІДу [1].

На жаль, Україна вважається країною з дуже високою інфікованістю вірусом, її середовище характеризується високим рівнем поширеності, й він може розповсюджуватися швидко, особливо серед молодих людей.

Тому обізнаність молоді щодо шляхів передачі ВІЛ та заходів профілактики ВІЛ/СНІДу є надзвичайно важливим фактором у боротьбі з поширенням цієї хвороби.

Основна частина. На сьогодні у світі понад 33,0 млн осіб інфіковані ВІЛ, з яких 2,2 млн - підлітки. Молодь $\epsilon$ основною епідеміологічною групою щодо ВІЛ [4].

За даними епідеміологів, більшість випадків захворювання на ВІЛ відбувається від безладних статевих зв'язків. Також небезпечними групами ризику щодо ВІЛ-інфікування $є$ ін'єкційні наркомани, проститутки. Передача ВІЛ від матері до дитини за останні кілька років також зросла [3].

3 метою з'ясування рівня обізнаності молоді щодо питань ВІЛ/СНІДу серед студентів Комунального

(с) О. А. Полоз, 2021 закладу «Олександрійський медичний фаховий коледж» було проведено анкетування.

Дослідження проводили за спеціально розробленою анкетою, що містила 30 запитань. Опитано 240 респондентів - студентів I-IV курсів Комунального закладу «Олександрійський медичний фаховий коледж».

Всього в анкетуванні взяло участь 240 студентів. Серед респондентів осіб віком 15-16 років (I-ІІ курси) було 89 (37 \%), 17 і більше років (III-IV) - 151 (63\%).

Поділ респондентів за статтю був таким: 47 юнаків і 193 дівчини. Із них I-ІІ курси - 18 юнаків (20\%) і 71 дівчина (80 \%); III-IV курси - 122 дівчини (81 \%) і 29 юнаків (19\%).

Як свідчать результати опитування, більшість опитаних студентів (64 \%) вважає, що володіє достатньою інформацією про ВІЛ/СНІД (етіопатогенез, клінічна картина, діагностика, лікування, прогноз, профілактика), із них $27 \%$ - респонденти I-ІІ курсів і 86 \% - III-IV курсів. Разом із тим, 36 \% недостатньо обізнані в цьому питанні. Із них 73 \% - студенти III курсів і 14 \% - студенти III-IV курсів, що свідчить про те, що під час навчання студенти-медики набувають більше знань, досвіду і навичок щодо проблеми (табл. 1).

Дослідження показало, що більша частина опитаних (251 (90 \%)) розуміє різницю між ВІЛ та СНІДом, і лише 26 респондентів (10\%) не мають відповіді. 
Таблиця 1. Фрагмент опрацьованої анкети

Чи володієте Ви достатньою інформацією про ВІл/СНІД

(етіопатогенез, клінічна картина, діагностика, лікування, прогноз, профілактика)?

\begin{tabular}{|l|c|c|c|c|c|c|}
\hline \multicolumn{1}{|c|}{ Варіант } & $\begin{array}{c}\text { Кількість } \\
\text { відповідей }\end{array}$ & Частка, \% & $\begin{array}{c}\text { Кількість } \\
\text { відповідей }\end{array}$ & Частка, \% & 3Кв & Частка, \% \\
\hline Курс & I-ІІ & I-II & III-IV & III-IV & & 64 \\
\hline Так & 24 & 27 & 130 & 86 & 154 & 36 \\
\hline Нi & 65 & 73 & 21 & 14 & 86 & 0 \\
\hline Утрималось & 0 & 0 & 0 & 0 & & 0 \\
\hline Всього & 89 & & 151 & & 240 & 100 \\
\hline Разом
\end{tabular}

Незначна більшість респондентів (125 осіб (52 \%)) не брала участі в інтерактивних заходах (бесіда, тренінг, вебінар, круглий стіл, конференція тощо) на тему, що стосувалася ВІЛ/СНІДу, і 115 осіб (48 \%) мали позитивну відповідь. Причому ці показники значно відрізняються залежно від курсу, на якому навчаються респонденти. Так, позитивну відповідь на це питання на I-II курсах дало 18 студентів (20\%) і 97 студентів (64 \%) III-IV курсів. Це свідчить про те, що під час навчання в медичному коледжі студентів активно залучають до інтерактивних заходів на тему, що стосується ВІЛ/СНІДу.

Результати опитування показали, що проблеми ВІЛ/СНІДу майже не обговорюють у колі друзів. Про це зазначили 232 респондента (97\%), і лише 8 респондентів (3 \%) обговорювали з друзями проблеми, що стосуються ВІЛ/СНІДу. При дослідженні даного питання, на жаль, з'ясувалося, що значна більшість респондентів (221 (92 \%)) не обговорювала цю проблему і в родинному колі.

Визначено, що більшість опитаних (199 (83 \%)) знає шляхи передачі ВІЛ-інфекції, і 41 особа (17\%) не мають відповіді на це запитання. У ході аналізу дослідження було також зафіксовано відмінності в рівні поінформованості залежно від курсу респондентів. Можна відзначити, що студенти I-ІІ курсів гірше обізнані щодо шляхів передачі ВІЛ-інфекції, ніж студенти III-IV курсів (табл. 2).

Таблиця 2. Фрагмент опрацьованої анкети

Чи знаєте Ви всі шляхи передачі ВІЛ-інфекції?

\begin{tabular}{|c|c|c|c|c|c|c|}
\hline Варіант & $\begin{array}{c}\text { Кількість } \\
\text { відповідей }\end{array}$ & Частка, \% & $\begin{array}{c}\text { Кількість } \\
\text { відповідей }\end{array}$ & Частка, \% & $3 K B$ & Частка, \% \\
\hline Курс & I-II & $I-I I$ & III-IV & III-IV & & \\
\hline Так & 54 & 61 & 145 & 96 & 199 & 83 \\
\hline $\mathrm{Hi}$ & 35 & 39 & 6 & 4 & 41 & 17 \\
\hline Утрималось & 0 & 0 & 0 & 0 & 0 & 0 \\
\hline Всього & 89 & & 151 & & & \\
\hline \multicolumn{5}{|l|}{ Разом } & 240 & 100 \\
\hline
\end{tabular}

Дослідження показало, що більшість опитаних (218 (91\%)) знає способи профілактики СНІДу, а 22 особи (9 \%) не мають відповіді на це запитання.

Також простежується поінформованість в даному питанні залежно від курсу респондентів. Можна відзначити, що серед студентів I-II курсів зі способами профілактики ознайомлені 68 осіб (76 \%), а серед студентів III-IV курсів 150 осіб (99\%). Незахищений секс, як один із способів зараження ВІЛ-інфекцією, визнали 95 \% респондентів, і лише 5 \% з них схилилися до іншої думки. Значна частина респондентів (87 \%) вважає презерватив надійним захистом від інфекції, 5 \% мають сумніви стосовно надійності його використання, а 8 \% не мають чіткої відповіді. Необхідно акцентувати увагу на тому, що мають можливість купувати презервативи самостійно та у достатній кількості лише 12 \% респондентів. Тобто молодь не має можливості за потреби купувати засоби захисту (59 \% респондентів відзначили високу вартість презервативів). Крім того, 32 \% респондентів вказали, що соромляться їх купувати, а 9 \% - на недостатність пунктів цілодобового продажу презервативів (рис. 1).

Опитування показало, що більшість респондентів (98 \%) вважає за необхідне застосовувати медичним працівникам захисний одяг при виконанні маніпуляцій, і лише 2 \% респондентів не мають відповіді на це запитання. Можна зробити висновок, що студенти медичного коледжу мають високу свідомість 


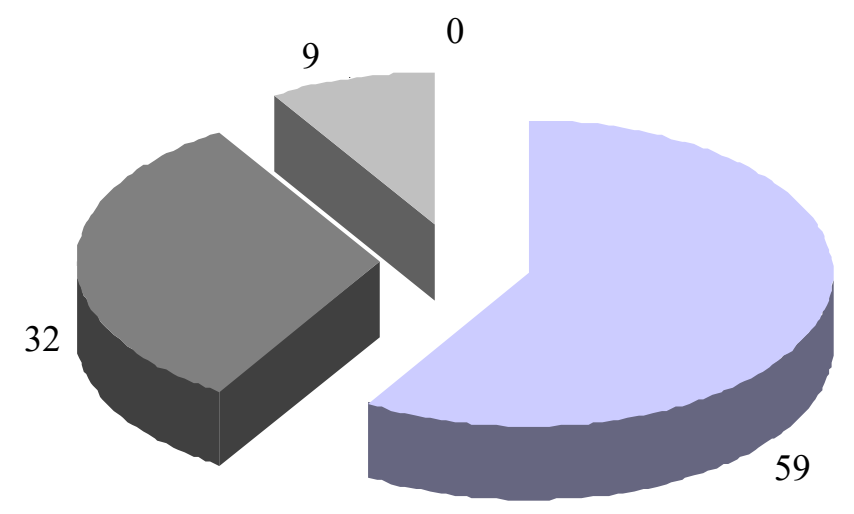

Висока вартість

Почуття сорому

- Недостатність пунктів цілодобового продажу

РUс. 1. Фактори, що перешкоджають молоді вільно купувати засоби індивідуального захисту, \%.

та розуміють необхідність використання захисного

одягу в практичній діяльності. Адже, $91 \%$ респон- дентів зазначили, що будуть використовувати захисний одяг при виконанні маніпуляцій (табл. 3).

Таблиця 3. Фрагмент опрацьованої анкети

Чи будете Ви використовувати захисний одяг (рукавички, маски, екрани) при виконанні маніпуляцій?

\begin{tabular}{|c|c|c|c|c|c|c|}
\hline Варіант & $\begin{array}{c}\text { Кількість відпо- } \\
\text { відей }\end{array}$ & Частка, \% & $\begin{array}{c}\text { Кількість відпо- } \\
\text { відей }\end{array}$ & Частка, \% & 3KB & $\begin{array}{l}\text { Частка, } \\
\%\end{array}$ \\
\hline Курс & $|-| \mid$ & $I-I \mid$ & III-IV & III-IV & & \\
\hline Tak & 79 & 89 & 140 & 93 & 219 & 91 \\
\hline $\mathrm{Hi}$ & 0 & 0 & 0 & 0 & 0 & 0 \\
\hline Іноді & 10 & 11 & 11 & 7 & 21 & 9 \\
\hline Утрималось & 0 & 0 & 0 & 0 & 0 & 0 \\
\hline Всього & 89 & & 151 & & & \\
\hline \multicolumn{5}{|l|}{ Разом } & 240 & 100 \\
\hline
\end{tabular}

За отриманими даними, можна зробити висновок, що попит на інформацію про проблему ВІл/ СНІДу серед молоді $є$ високим. Адже, більша частина опитаних (143 (60\%)) відчуває потребу поповнити свої знання з цього питання, особливо це стосується респондентів І-ІІ курсів (60\%).

Досліджено, що більшість осіб (68 \%) володіє інформацією, де можна пройти обстеження на наявність ВІЛ-інфекції, але простежується залежність

0

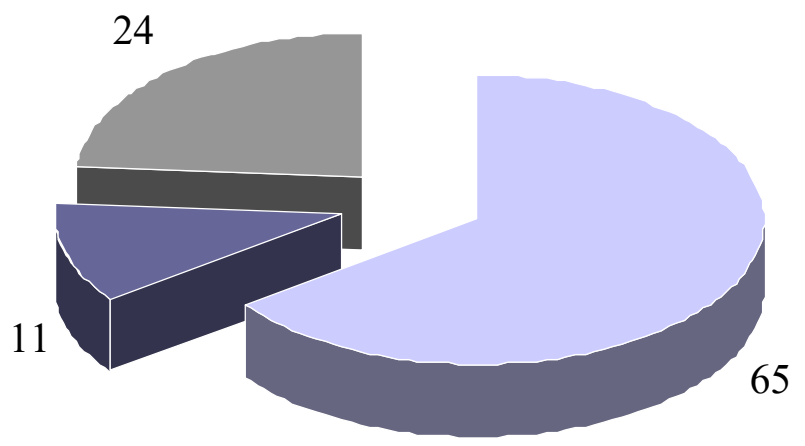

PUс. 2. Ставлення до людей, яких торкнулася проблема ВІл/СНІДу, \%
Більшість респондентів (81 \%) відповіла, що ВІЛінфіковані не потребують ізоляції від оточуючих, а 19 \% мають протилежну думку. За результатами поінформованості від курсу навчання респондентів. Так, із 89 опитаних I-II курсів, лише 13 осіб (15 \%) знають відповідь на це запитання.

Дослідження показало, що студенти медичного коледжу є досить толерантними стосовно людей, яких торкнулася проблема ВІЛ/СНІДу. Так, 65 \% респондентів відзначили, що продовжать спілкуватися з ВІЛ-позитивним другом, 11 \% припинять спілкування, і 24 \% не мають відповіді на це запитання (рис. 2). дослідження, більшість респондентів (62 \%) готова працювати з ВІЛ-інфікованими пацієнтами, 13 \% не погоджуються, і 25 \% не мають чіткої відповіді. 
Висновки. У результаті проведеного дослідження визначено достатній рівень обізнаності студентівмедиків щодо запобігання інфікуванню та основні проблеми зниження ризику зараження ВІЛ. Ключова проблема полягає у незабезпеченості вільного доступу молоді до засобів індивідуального захисту

\section{СПИСОК ЛІТЕРАТУРИ}

1. ВІЛ-інфекція в Україні : інформ. бюл. / МОЗ України, Укр. центр профілактики і боротьби зі СНІДом, Ін-т епідеміології та інфекційних хвороб ім. Л. В. Громашевського АМН України, ЦСЕС МОЗ України. - 2010. - № 34. - 41 с.

2. URL : http://ukraids.gov.ua/ (сайт Українського центру профілактики і боротьби зі СНІДом).

3. ВІЛ-інфекція в Україні : інформ. бюл. [Електронний ресурс] / МОЗ України. - 2010. - № 32. - Режим доступу : http:// dssz.gov.ua. - Назва з екрана.

4. Подростки групп риска: доказательная база для усиления ответа на эпидемию ВИЧ в Украине : аналит. отчет / ЮНИСЕФ, УИСИ им. А. Яременко. - К. : КИС, 2008. - 192 с. та недостатньому заохоченні підлітків до здорового способу життя засобами масової інформації. Вирішувати їі необхідно комплексно, спільними зусиллями усіх дотичних суб'єктів та інституцій, змінивши політику протидії епідемії ВІЛ/СНІДу в Україні у цілому.

5. Надання медико-соціальних послуг дітям та молоді на основі дружнього підходу : методичні рекомендації. K., 2008. -6 c.

6. Вместе против СПИД : пособ. / Республиканский центр профилактики СПИД, Министерство образования, ЮНИСЕФ, 2003.

7. Нормативно-правовий огляд щодо профілактики ВІЛ/СНІД та доступу до медико-соціальних послуг серед підлітків, у тому числі підлітків груп ризику. - К., 2012.

Отримано 23.04.21 